\title{
Chinese Innovative Teaching Strategies of Minority Preparatory University under the Realistic Background
}

\author{
Yanyan $\mathrm{Pi}^{1,}$, , Fangfang Xiong ${ }^{2, \mathrm{~b}}$ \\ ${ }^{1,2}$ Nanchang Institute of Science \&Technology, Nanchang, Jiangxi, 330108 \\ ${ }^{\mathrm{a}}$ email, ${ }^{\mathrm{b}}$ email
}

\begin{abstract}
Keywords: The Realistic Background, Ethnic Minorities, Preparatory University Chinese,
\end{abstract} Innovative Teaching Strategies

\begin{abstract}
With the deepening of the new curriculum, teaching reform is increasing popular in the major universities. As one of the most important lessons in many languages subjects, the strengthening and enhancement of the Chinese teaching quality and teaching efficiency has a very important role on the development of Chinese education industry. Minority preparatory university language teaching, because of its specificity, its educational goals are only to students of the humanities and aesthetic culture as the basis, so in order to promote students' cultural qualities and language quality to have further improved. During the process of teacher education, it should be combined with the characteristics of language courses, using a variety of innovative teaching strategies, will fall under the Chinese University Students Humanity Quality training system, so in order to let the overall efficiency and quality of teaching has been effectively improved. In this paper, a brief analysis on language teaching strategies and innovative University College Minority under realistic background is conducted, hoping to bring some help to improve our Minority Preparatory College Chinese teaching efficiency and quality.
\end{abstract}

\section{Introduction}

Due to the special nature of minority students, many minority preparatory college students still there is a big lack in language skills, lack of on board extracurricular reading motivation and weak writing skills, to promote teaching efficiency Foundation University College of minority languages and quality is always difficult to be effectively improved. The language courses to enhance students 'cultural literacy as an important channel, its main purpose is to teaching in the humanities and aesthetic based on the students' humanistic qualities and promote the overall quality of the Austrian can effectively improve. Accordingly, aspects of minority language teachers Foundation University, and only continue to explore and analyze the practical aspects of teaching language courses, the use of a series of innovative teaching strategies to enhance allowed to Minority Students Humanities Qualities role into full play.

\section{Flexible Application of Textbooks}

Since the family environment, social environment and other factors, each student's language level also mostly there are some differences, so while each student used textbooks are the same, but their interpretation of the text was largely the same level. For this, the teachers in their daily teaching process should be directed to school students, students at different levels appropriate to adjust the number of hours per week as well as teaching methods and objectives, and if the lower Preppy Chinese quality level, it should be combined with the actual situation, and the difficulty of teaching objectives appropriate to reduce, but may be appropriate to increase the amount of hours per week, strictly follow the principle of individualized [1]. The only way to make all levels of students are able to learn and acquire more knowledge, which can be their language ability and human qualities be effectively improved.

Integration mainly refers to the teacher should be combined with the actual situation of each student, in language teaching materials and teaching content reasonably integration. Since there are some differences and general education for college preparatory teaching, their teaching time is not 
very long, often only one or two years. Therefore, in order to make teaching efficiency and enhance the effective treatment, it must be the actual situation in the process of teaching students and daily exhibited to textbook-based, scientific and rational integration of text content and teaching methods. For example: PEP university language teaching materials and books on lower volumes, is in chronological order, using the genre plate set a plurality of cells, each cell in the selected text in five or more.

The so-called reality mainly refers to, in the teaching process, teachers should be combined with the actual situation of the preppy set course content and objectives. In the course of the text should be interpreted in reality based on the special nature of the target institutions to achieve full understanding of the different levels of students do fully grasp. Mostly some ethnic minority language teaching preppy college preparatory faced by teachers during the teaching process and therefore should be in the reality of students, the goals are reasonable, in order to be different levels of syllabus It worked out, so in order for the overall efficiency and quality of teaching have been fully upgraded, the true realization of human culture quality of language teaching training objectives.

\section{Reform and Innovation into Teaching Mode}

Butler learning mainly through profiles, motivational, organizational and teaching evaluations, consolidate and expand the way to stimulate students' interest in learning to improve overall efficiency and quality of teaching. During the time profiles can be divided into four, the first problem is to build scenarios through problem situations to make students 'learning objectives are clear, allow students to explore the desire to get excited, so as to effectively enhance the students' interest and passion [2 ]. Second scenario is to build the story, interesting story can be attracted the attention of students, which will help guide students into a new lesson. The third is to build life situations, usually through life situations allows students to face a series of knowledge becomes more vivid, which will allow students to get a sense of familiarity to strengthen knowledge, can play an immersive Effect. Finally, the game scenario is set, the game allows students to stimulate students' interest in learning, thus contributing to a proactive patient into the study, and to enable them to master the knowledge acquired in the course of the game fun.

Phenomena mode is a constructivist theory of cognition, which is divided into the teaching process to produce phenomena, explanation, and then to analyze the results and methods. This teaching mode that allows students in the teaching process, by means of the essence behind the phenomenon revealed in this teaching mode, students can give full play to the subjectivity [3]. By allowing students to own the essence behind the phenomenon into the explanation, which will not only allow students to participate in the enthusiasm effectively excited, but also allows students to the dominant position in the teaching process has been fully demonstrated, prompting the analytical capacities of students get training while effectively enhance its comprehensive ability.

The main role of this teaching mode, there are two, one is the systematic knowledge to the students, and the other is for students' basic skills to effectively train. Its main purpose is to allow students to achieve more rapid and efficient information of knowledge and understanding by the students of memory and reasoning ability to fully develop ways to let the object can be achieved. In addition, during the use of the teaching model, you want to ensure their effectiveness, the teacher must be reasonable to use a variety of presentation skills, in order to allow students to take the initiative to accept, willing to accept, the only way to let the action get give full play to make teaching efficiency and quality can be effectively improved.

\section{Enhance the Overall Quality of Teachers}

First, the relative ratio of professional and foreign language teachers college, university preparatory language teachers do not want to do alone on literature and language and culture involved relates ancient and modern, knowledge content in the knowledge, but also need to have a wealth of history and philosophy knowledge base and higher overall quality, the only way to achieve ease in the 
language teaching college preparatory process. Secondly, preparatory language teachers also need to have a certain level of language arts level, such as the language of innovation, dynamism and charm, etc., the only way to make classroom teaching efficiency is further optimized through its own strong language art to allow students to get influence, thereby language skills so that students can be effectively enhanced and training [4]. Finally, the necessary preparatory language teacher professionalism, and full of passion, emotion-rich also has a very important significance, only teachers in their daily lives, the work process is full of passion and full of rich emotion, and by passing to continue infected students, promote their own personal charm can be brought into full play so as to make the guiding status of teachers in teaching have been a real show, students and even the future development of the students have a positive and positive impact.

\section{Conclusion}

All in all, along with the deepening of the new curriculum, teaching reform range will continue to expand. In the reality of the current educational background, language teaching Minority College Students watch only realistic, practical teaching based on teaching out by focusing on flexibility, innovative teaching model and a series of innovative teaching strategies, continue to stimulate students' interest in learning and passion, so efficiency and quality of teaching minority language teaching college preparatory effectively is improved, so that the true role of language courses is full played, thereby promoting students' cultural quality can be further strengthened.

\section{References}

[1] Guo Sanli. Situation and Countermeasures of Ethnic Preparatory Chinese Teaching - A Case Study of Aba Teachers College preparatory education [J]. Aba Teachers College, 2011, 03: 115-117.

[2] Wang Zulong, Ruan Yuming. Mainland Universities and Strategies of Acculturation Preppy Xinjiang Minority Nationality - Minority Preparatory Three Gorges University Education [J]. Forum Three Gorges (Three Gorges • Literary Theory Edition), 2014, 06: 121-126.

[3] Lin Zhijie. Chinese Minority Preparatory Education and positioning-A Guangxi Minority Education Foundation Base Case [J]. Guangxi University for Nationalities (Philosophy and Social Science Edition), 2016, 01: 125-129.

[4] Yang Sheping. Contents of Ethnic Preparatory Mathematics Curriculum reform and innovative approaches. Also on National Minorities preparatory education bases "in Guangxi mode" [J]. Guangxi University for Nationalities (Natural Science), 2013, 03: 100-103. 